\title{
TOURISM OF FAMILIES WITH THE DISABLED CHILDREN OR WITH SPECIAL NEEDS IN POLAND OF RECENT DECADES
}

\author{
Marek Kawa \\ Janusz Korczak University in Warsaw, Poland
}

\begin{abstract}
The last decades in Polish society have been seen not only an increase in empathy and outlining needs for families and children with disabilities or deficits, but also economic improvement of families, which enables tourist or rehabilitation trips at least once a year. The growing needs and good practices for disabled children and adults also contributed to the greater awareness of the people managing of tourist centers in Poland, who are increasingly trying to propose within their offer to such groups, not traveling so far. This brief study tries to provide in a condensed way to propose good practices and experiences to meet the problems of families traveling with disabled children or adults in Poland.
\end{abstract}

Keywords: disabilities, disorders, family, tourism of disabled, travelling of disabled in Poland, good practises.

To cite this article:

Kawa, M. (2021). Tourism of Families with the Disabled Children or with Special Needs in Poland of Recent Decades. Innovation. Diversity, 2(3), 6-15. DOI: https://doi.org/10.17770/eid2021.2.6717

\section{Introduction}

There are currently around 650 million people with disabilities in the world, of which around 4.5 million only in Poland. Due to the difficult financial situation of families, mostly caused by the fact of staying with a disabled child for life at home of one of the parents, the vast majority choose solely domestic trips. According to research made by T. Skalska, in 2004 around $21 \%$ of people with disabilities travel in Poland, while according to our research, at least once a year, $60 \%$ of families go away, and only $12.7 \%$ twice (Skalska, 2004). Most often these are trips within the regions of Poland, travels abroad are declared by about $10 \%$ of respondents.

In relation to healthy (normative) Poles, people with disabilities travel three times less than the former. Their participation in international travel is fourteen times smaller (Analiza..., 2007). For many people, rehabilitation trips remain the only chance to see the Baltic Sea, Mazurian lakes... etc. or the capital of the Tatra Mountains - Zakopane. There is no publicly available statistics on travel in Poland people with disabilities, and tourism preference studies are carried out sporadically and to a narrow extent, which makes it difficult to generalize the issue.

From the point of definition of disability, we treat discrepancies of variety of definitions more freely. We are aware of plethora of arguments and disputes over definition of disability. Therefore, we will use such terms as 'intellectual impairment', 'intellectual disability', 'developmental disability' and 'mental retardation' interchangeably in the context of intellectual and mental disability. On the other side towards physical disabilities we are prone to use more open and larger approach. There are two terms in English for a person with a disability and handicap. The first is a person with disability, and the second is a handicap person. The former emphasizes the physical dimension more and is rather a medical term. The second term emphasizes impairment in the sense represented by functioning, and therefore emphasizes the social aspect. In practice, there are no major differences between them and both terms are used interchangeably (Majewski, 1980). After professor of Jozef Sowa, we are following his more open definition of disability:

"A person with disability is someone in whom the damage and reduced fitness level of the organism made it difficult, limited or impossible to perform life and professional tasks and 
fulfill social roles, taking into account their age, gender and environmental, social and cultural factors (Sowa, 1999).

People with physical disabilities should be constantly rehabilitated. Parents of such children must take care of the most common breathing and relaxation exercises, equivalent or improving, to facilitate the functioning of healthy people in the world. Exercise in water or an hippo therapy, which often take place outside the place of residence, usually during the break school time can be helpful in rehabilitation too. For recent 40 years there have been tries to help disabled people to fulfil their sightseeing and tourist dreams, offering various forms of touristic activity. It is tourism that builds emotional bonds with the landscape, with Poland, with people who wander and people inhabiting the regions of visit. On the tourist route, everyone is equal in the face of nature and other people. Due to a given disability, people with disabilities have special needs regarding holidays, which mainly correspond to the accessibility of transportation, accommodation, sights, infrastructure, tourism services (Pühretmair, 2006).

The material below is based on some parts of the report of international project ELISE (The Eliminating Social Exclusion), which was conducted by partners from Poland, Greece, Turkey, Spain, Latvia and Bulgaria in 2019-2022. Based on the desk research and also collecting experience of foreign partners of the ELISE project (ERASMUS PLUS) and comparing with Polish experience in this field there were presented some conclusions and propositions of good practises and main problems of Polish families who have been trying lately to travel with the disabled children.

\section{Regulations available to support the travel needs of families with the disabled children and adults}

In the Polish law there are some regulations which refer mostly to the group of people with disabilities but there is no a particular law or bill which might regulate situation of such people in the circumstances of travelling. For instance the Polish Constitution states in general way about human rights of everyone without discrimination:

Everyone is equal before the law. Everyone has right to equal treatment by public authorities (The Constitution of the Republic of Poland of April 2, 1997, Art. 32. 1). No one may be discriminated against in political or social life or business for any reason; (The Constitution of the Republic of Poland of April 2, 1997, Art. 47). Everyone has the right to the legal protection of private and family life, honor and good name and to decide about your personal life; Everyone has the right to health protection... (The Constitution of the Republic of Poland of April 2, 1997, Art. 68.1).

There is also in the international law an important convention named the Rights of Persons with Disabilities which was adopted on December 13, 2006 by the United Nations General Assembly (Convention.... 2006) and later implemented by many of 192 member countries, including Poland. Poland also accepted the Charter of the Rights of Persons with Disabilities of August 1, 1997 (MP of August 13, 1997, No. 50, item 475), which states that people with disabilities are persons whose physical, mental or mental fitness permanently or periodically hinders, limits or prevents daily life, education, work and social roles in accordance with legal and customary standards. This is the law approach towards definition of the disabled persons which not always complies with the latest established definitions in a scholar literature.

Many years ago in Poland there was implemented the Legal Act (Journal of Laws of 1997, No. 123 , item 776 , as amended) which had been in some parts referring to the required conditions for the all groups of people with disabilities which would ease and help the functioning better in society. It was called: The Act of 27 August 1997 on professional and social rehabilitation and employment of people with disabilities (Journal of Laws of 1997, No. 123 , item 776, as amended). 
Relating to children with some degrees of disabilities in Poland there was implemented on January 1, 2002, a disability certificate (Rozporządzenie Ministra Pracy i Polityki Społecznej..., 2002) for children under 16 years old for the purposes of obtaining nursing allowance, permanent allowance for caring of a child with social assistance, rehabilitation and treatment purposes.

More detailed laws regulating issues and problems of movement or technical which may affect tourism of the disabled people (including children) in Poland can be found in some minor acts. The disability certificate contains indications regarding, among others, the need to supply orthopedic items, auxiliaries and technical aids, facilitating functioning, the need for permanent or long-term care or assistance of another person in connection with the significantly limited possibility of independent existence, the need for permanent participation in every day of the child's care giver in the process of his treatment, rehabilitation and education, meeting the conditions specified in art. 8 clause 1 of the Act of 20 June (Ustawa o ruchu drogowym..., 1997). Such an assistance should include also help during the movement because of the touristic causes.

There are also in Poland some other more detailed documents referring to such a special group of Poles, an example of such a solution is the Regulation of the Minister of Economy and Labor from 2004 devoted to giving categories to hotel facilities (Rozporządzenie Ministra Gospodarki i Pracy z dnia 19 sierpnia..., 2004). This document introduces, among others rules for making such facilities available to people with disabilities.

The problem of tourism of people with disabilities was also raised, albeit only to a small extent, as a part of the draft Tourism Development Strategy for 2007-2013 (Strategia Rozwoju Turystyki na lata 2007-2013, 2005). Written for the broader concept of the National Development Plan, the document prepared by the Tourism Department of the Ministry of Economy sat directions for the harmonious and coherent development of tourism as one of the branches of the Polish economy.

By the way of regulations of such areas in Poland as public transportation there are some references to situations of the disabled like in the Act no. 02.179.1495, with further amendments issued as "Regulations of the Minister of Infrastructure from 25th October 2002 on the types of documents confirming the right to use concessionary public transport services" (Rozporządzenie...., 2002). Poland also accepted the Regulation (EC) of the European Parliament and of the Council EU No. 1107/2006 of 5 July 2006 on the rights of persons with disabilities and persons with reduced mobility traveling by air (Rozporządzenie (WE) NR 1107/2006).

Many issues regarding the provision of buildings and space for people with disabilities in Poland are governed by the provisions of the construction law and the law on spatial development. However, people with limited mobility themselves specify the requirements that their environment should meet to remove barriers. For recent years the majority of public buildings (including schools) have been adjusted to such physical requirements of people with disabilities including students and kids too.

The problems of people with disabilities in the context of tourism, though, appear in the most important document of programming Polish development tourism for the coming years, however, still it does not treat it as a separate area of issues. 


\section{Identifying the primary and secondary needs for the families with the disabled children and adults}

M.A. Devine has shown that $28 \%$ of the US population of people with disabilities travel outside of their own territory (Disability and Development Report..., 2004 ). The distances that families with members carrying disabilities can get through for tourist purposes depend on the type of child dysfunction. M. Milewska showed that $20 \%$ of people with physical disabilities travel in Poland. A much larger difference occurs in the case of mentally ill people, because according to M. Milewska they travel the least often, which was not confirmed in the presented work (Milewska, 2008).

Needs of the disabled people are generally the same as for the healthy part of the population, but they require support in a creative way to fulfill specific social roles in the best of their abilities. It is widely believed that people with disabilities in Poland have been ones of the most marginalized groups and have been constantly experiencing restrictions on access to any field of social life.

The level of participation of people with disabilities in tourism is also marginal, despite its undeniable values and positive rehabilitation effects.

Adults with disabilities belong to active participants of society, making a significant contribution to its development. On the other hand, a medical model instead defines disability through the lens of health, perceiving it as a disease, which is under the control of doctors and rehabilitation specialists. Among adults who are categorized as the disabled there are some who declaring their stay outside of the place of residence, only $30 \%$ of them took part in tourist and leisure trips, $28 \%$ in health care, while most trips concerned visits of relatives and friends. Due to the type of disease, people with cardiovascular diseases travel most often $(21 \%)$, while the least people with mental retardation and mentally ill (15\%), as well as people with hearing impairment (Milewska, 2008).

Beside issues of adults we should also take into account a tourism of disabled children. This sort of tourism should be treated as part of the rehabilitation with elements of therapy for disabled people, whose main goal is to restore maximum physical, mental, social and professional fitness and adapt to normal life. Tourism of people with various disabilities should be treated not only as active leisure, but also as therapeutic and educational measure, enabling everyone to handle it at various, often harsh conditions. Some data referring to question about the means of transportation during such touristic trips indicate that respondents definitely most often choose a car and then rail as a means of transport during travel in Poland. Parents of children with physical disabilities do not use buses and planes at all, choosing trips within a given region of Poland (Poland is divided into administrative regions which are called by term of a 'voivodship') most often (51.7\%). A similar destination is preferred by parents of children with multiple disabilities (65.4\%), while parents of blind or deaf children travel throughout the country (over $60 \%$ of respondents). Probably for financial reasons, the vast majority of Poles go with the child only once a year. For parents of mentally handicapped children $43.8 \%$ declare that they travel less than once a year (Milewska, 2008).

Regardless of the type of child disability, most often decide on trips which are organized on their own. An organized travel is popular among families with a blind child (18.5\%), while specialized camps dedicated to particular disability among children with physical disabilities $(17.9 \%)$. Active recreation is preferred by families with deaf children $(60 \%)$ and mentally retarded children $(51.4 \%)$, while most families passively rest with children with motoric dysfunction (71\%) and multiple disability (65.4\%) (Milewska, 2008). Other data indicate that parents of disabled children most often use the offer of private accommodation. Guest houses are also popular because of specific touristic market in Poland still strongly based on private 
guest houses. Parents of deaf children choose to send them to holiday homes and campsites ( $20 \%$ of parents surveyed each), while parents of blind and disabled children use rather hotels (24.1\% and $15.2 \%$, respectively).

Most obstacles related to the lack of infrastructure adaptation during trips are declared by parents of children with physical disabilities (80\%), multiple disabilities (63\%) and blind children $(44.4 \%)$. The problem of parents with a mentally retarded child is usually intolerance $(56.3 \%)$. Parents of deaf children in general, $60.0 \%$ have no major objections during traveling (Milewska, 2008).

Rehabilitation visits are most popular among families of children with motoric dysfunction (92.6\%) and multiple disability (76.9\%). In the case of deaf children, $80.0 \%$ of them do not use the option of going to such visits (Milewska, 2008). Another factor hindering the tourism of children with hearing impairments is the problem of focusing attention, arousing curiosity, eyes arousing interest. Camps or other forms of organized tourism for children may not be suitable for deaf children because it is more difficult for them to make any interpersonal contacts. They often have egocentric habits that make it difficult to function in a group.

Vision disability, according to (Kędzierska, 2007), has a medical, social, psychological and didactic dimension. The sight itself should be considered in the categories of cognitive, practical activity, spatial orientation, emotions and interpersonal communication. A tourism adapted to the needs of the blind people is a demanding challenge for the organizers. In the case of the blind people and partially sighted children, it should be taken into the consideration that any form of activity should be combined with rehabilitation that will facilitate their efficient life in society.

The tourist accommodation must meet the following requirements for persons, including families with blind and visually impaired children:

- open spaces and paths free of obstacles,

- explicit and accurate descriptions of the environment to help experience surroundings and obstacles,

- well-lit and high contrast marking,

- the possibility of touching objects in the immediate surroundings,

- acoustic signals for obstacle or dangerous determination place,

- the use of documents and forms in Braille,

- information on CDs, DVDs, floppy disks etc. or in the alphabet Braille,

- an assistant available to assist you in special cases.

Due to the fact that tourist information is often distorted, most respondents individually organize their family trips (over $81 \%$ ). The obtained results indicate that the goal of $50 \%$ of travel was passive rest, while active holidays were declared by $29 \%$ of respondents. The most therapeutic, from the point of view of rehabilitation, is the form of active tourism that has a positive effect on health, develops physically, aesthetically and morally. According to the research of K. Kaganek and H. Stanuch, the most favorable for people with visual disability is the cognitive factor, which is confirmed by the results of the study. In their research $35.7 \%$ of respondents declared "visiting" among families with blind children (Kaganek \& Stanuch 2005).

Still there can be observed many wrong ideas about deaf adults and children in society. The consequence of this situation of misunderstanding is a tendency to avoid hearing contact with hearing impaired people and vice versa. Such reluctance of the sides is due to the stage of fright and fear of talking to someone who does not know the language of another person. People who are deaf and hearing-impaired, despite the accepted opinion, are disturbed by noise as much as people who can hear. A deaf person with a damaged middle ear is sensitive to noise and vibrations, and the hearing impaired people do not have good sound selection skills and may pick up the wrong sounds in the situation of unexpected noise. 
The time of hearing loss has a huge impact on the socio-psychological situation of people with hearing disabilities - apart from the popular stereotypes. Children who lost their hearing after the age of 5, i.e. after completing language learning, are able to use audio speech. Those who have lost their hearing in older age, but have not mastered sign language are suspended between the world of hearing and deaf people (Milewska, 2008). They are not identified with any of the groups. The deaf people who were born with such disability, called culturally deaf, they create their own social group. They easily make contacts with each other and exchange information, because of different communication they think specifically. Therefore, this is a reason for their perception as a mentally retarded group. Thus, such reasoning is obviously wrong (Milewska, 2008).

Hearing impaired people are sometimes treated as nervous and aggressive ones. They often give the impression that they are disregarding the interlocutor. It includes those who communicate effectively with hearing people by reading speech from their mouths. They make breaks in the conversation because they are no longer able to focus their eyes and attention on the interlocutor's lips.In this context of internal conditions it makes deaf people feel better to deal and communicate in a similar environment. The conversation does not require much effort from them and is more pleasant (Milewska, 2008). This approach further isolates this group of disabled people from the rest of society. Integration of the deaf and hearing impaired should therefore consist in accepting the need to have their own environment, and rehabilitation should lead to equal opportunities for hearing-impaired people.

People with intellectual disabilities, often showing intellectual retardation, must learn basic life activities, cannot play, often have to learn to live together and work with peers, hence the important role of rehabilitation sessions or integration camps. It should be remembered that children/adults with intellectual disabilities in their environment expect friendly guides, guardians and visual signals that will diversify their impressions. The most dangerous for this group of disabled people is noise - disturbing, distracting and disrupting the reception of signals coming from the outside.

However, sport and tourist activity of the disabled faces a number of barriers. Research conducted in a group of people with various dysfunctions show that one of the most important barriers to tourist activity are organizational difficulties and lack of information (Skalska, 2004). Among dozens of travel websites operating on the Internet, none of them treat people with disabilities as customers with different needs. They are missing in them also information on travel amenities and the availability of hiking trails.

On the other hand people with disabilities can increasingly engage in water sports, such as canoeing and sailing, and winter sports (trekking, ski-mountaineering). There is a little known about this, but people with disabilities have been practicing even the most difficult types of qualified tourism in Poland for many years, such as skydiving, diving, sailing or canoeing (Szczuciński, 2005).

Plethora of research done in Poland throughout the period of 2007-2015 among adults with disabilities indicate similar group of answers. For instance the vast majority of respondents do not feel a fear around them that could be another barrier in tourist and in recreational activity. A significantly higher percentage of the unemployed and inactive respondents in the study group in relation to the group of working people considered communication difficulties as a serious limitation (Żbikowsk \& Soroka 2011). Factors such as: fear of people, lack of help on the part relatives, the lack of facilities associating people with disabilities do not significantly discourage people with disabilities especially in the Lublin region (the south-east part of Poland) from tourism and recreation (Żbikowski \& Soroka 2011). To sum up research made in this particular region of Poland (Lubelskie Region) we may conclude that: the largest percentage of respondents do not feel fear of people with whom they would come into contact during travelling, sport and recreation, which indicates the openness of people with disabilities 
and the desire to make new contacts during active rest. The attitude of people with disabilities should be assessed positively, which is characterized by great interest in tourist activity and recreational, and the possible lack of help from the loved ones is not a main obstacle in their intentions to implement real actions. The disabled people living in the Lubelskie Voivodeship (a south-east part of Poland) considered as insignificant or insignificant barriers to participation in tourism and sport and recreational activities identified during the research.

This is an optimistic phenomenon from the perspective of the development of the tourist and recreation market, which should focus its offer more on the segment of the disabled market.

\section{Good practices and initiatives. Propositions of improvements}

In Poland mostly a third sector of NGOs is trying to response to challenges of social tourism. Also implementing a results of the EU pro-social projects. For example: a project named - "In the world beyond Silence and Darkness" conducted in 2012 by foundation "Zdążyć z Pomocą" ("Be on time with help...") - a foundation for children in cooperation with PTTK ("The Polish Society of National Tourism") became the organizer of anti-discrimination training for tourist guides. Project "In a world outside of Silence and Darkness" was not only raising qualifications and acquiring new ones skills, but also broadening the guides' view on the problems of the blind and visually impaired people.

Conclusions of mentioned project direct to some proposals of sustainable development of tourism of people with disabilities through individual elements of travel in Poland:

\section{Table 1 Proposal of sustainable development and good practices of tourism of people with disabilities through individual elements of travel in Poland}

\begin{tabular}{|l|l|l|}
\hline \multicolumn{1}{|c|}{ Elements of travelling } & \multicolumn{1}{|c|}{ Now } & \multicolumn{1}{c|}{ Needed to do/ Future } \\
\hline $\begin{array}{l}\text { 1. Access to touristic } \\
\text { information. }\end{array}$ & $\begin{array}{l}\text { city guides, internet, folders, } \\
\text { leaflets }\end{array}$ & $\begin{array}{l}\text { more details on the maps, more } \\
\text { widespread. }\end{array}$ \\
\hline 2. Travel preparation & $\begin{array}{l}\text { specialized travel agencies, } \\
\text { organizers }\end{array}$ & $\begin{array}{l}\text { increasing the number and } \\
\text { scope of activities }\end{array}$ \\
\hline 3. External communication & good and bad situation & $\begin{array}{l}\text { increasing accessibility to } \\
\text { railways, ferries, bus transport } \\
\text { and aviation }\end{array}$ \\
\hline 4. Internal communication & $\begin{array}{l}\text { depends on personal and local } \\
\text { circumstances }\end{array}$ & this element requires enhancing \\
\hline $\begin{array}{l}\text { 5. Travel destination, (open air, } \\
\text { museums, monuments) }\end{array}$ & it depends on type of disability & more detailed information \\
\hline 6. Accommodation, housing & variety of offers & $\begin{array}{l}\text { more detailed information on } \\
\text { special equipment in } \\
\text { accommodation }\end{array}$ \\
\hline 7. Feeding & $\begin{array}{l}\text { good conditions } \\
\text { information }\end{array}$ \\
\hline 8. Functionality & $\begin{array}{l}\text { barriers and limitations in } \\
\text { connection with a particular } \\
\text { type of disability }\end{array}$ & $\begin{array}{l}\text { abolition of barriers and } \\
\text { limitations }\end{array}$ \\
\hline
\end{tabular}

Source: Author's proposition.

So far in Poland there have been completed some programs dedicated to families with members carrying disabilities. Next examples may be added, for instance:

"Tourism for All" implemented by the "Polish Tourist and Country Fans' Society" with the support of the Government Program of Civic Initiatives Fund. As part of the pilot project 
carried out in Łódź City, the Masovian Region and the Podlaskie Region, the availability of various types of facilities is checked: accommodation, catering, cultural, sports, but also tourist routes, national and landscape parks or means of transport. An important element of the project is a website containing lists of facilities adapted to the needs of people with disabilities, which can be searched in terms of their location or type of amenities offered (Grabowski, Milewska, Stasiak 2007).

Another example of internal institutional initiatives in Poland - a project called „Let's take the first step" was run and implemented by the State Vocational University of John Paul II in Biała Podlaska City a training system for the environment cooperating with disabled people. One of the main goals of the project was:

1. to break stereotypes in perceiving the role of people with disabilities in society by carrying out information and education campaigns that promote a change in the way people with disabilities are perceived as defective citizens;

2. preventing social exclusion of people with disabilities by overcoming problems associated with limiting access to public services and restrictions on the possibility of professional activation. Although the project is mainly aimed at improving the situation of people with disabilities on the labor market, its impact on other areas of life of people with disabilities cannot be excluded (Grabowski, Milewska, Stasiak 2007).

There are also some infrastructure improvements widely introduced in Polish hotels like for example for adults and kids with physical limitations, especially using wheelchairs.

For instance a cable-car or city buses that can be entered stepless is a requirement of use for about $10 \%$ of the population. For approximately $30-40 \%$ a stepless access simplifies the use and for $100 \%$ of the population it is an argument of comfort. A higher number of accessible facilities and services make traveling easier and increase the comfort factor when enjoying holidays (Pühretmair, 2006). In these days majority of Polish public transport must have a special area for those passengers with special needs. In addition, people with limited mobility in cities can also use cabs (taxi) today. Vehicles specially adapted for them are available to this group of people, however, the fact of disability should be reported at the time of ordering. Many privileges for a person with disability give possession of card parking. It is a document that all countries belonging to the European Union recognize, and which allows parking in designated places and inaccessible to people with disabilities. However, in some countries the parking card entitles people with disabilities to other types of concessions and when they stay abroad, they must comply with the regulations in force in that country. Below we enclose also some advices for young, children and their families who deal with some problems during travelling:

- $\quad$ when giving directions, do not use terms that are understandable only for the sighted person;

- when talking turn always to the blind person instead of a person accompanying him/her;

- $\quad$ when in a room with a visual disability try to put all objects in their place or inform them about any changes;

- $\quad$ express your gestures in words, e.g. willingness to shake hands (do not grab the hand beforehand);

- $\quad$ warn about your willingness to help;

- $\quad$ choose the option of help accepted by a blind person; when you're in a hurry, don't offer your help so that you don't have to leave such person unattended;

- $\quad$ helping the blind, warn about obstacles, change of direction;

- giving a chair, do not place a blind man on it, but place his hand on the backrest;

- plan your time well, without leaving too much for unorganized activities - the blind people in a new place feel insecure. 
Another large group of the disabled are deaf adults/children. Their activities should be supported, unrestricted access to mass media should be provided as well, and they should be provided with appropriate technical means supporting the hearing process. However, they must not be forced to teach speech and make deaf people like hearing people. It is also necessary to prepare social services for contact with deaf people, e.g. by learning sign language loop should be European standard. The tourist base should be properly technically prepared to support the hearing impaired and deaf people and use such solutions as (Budny, 2003):

- information in writing (brochures, guides, guides) on the adaptation of the facility to service guests with hearing disabilities;

- phones with audio-visual function;

- facilities using Bluetooth technology, signaling devices and vibrations;

- alarm systems with audio-visual function;

- teachers - sign language interpreters;

- telephones, videophones with the teletexting option,

- television broadcast with the option of sign language translation,

- textual information on all relays (devices) TV / Video.

Information for the deaf and hearing impaired guests should be mainly provided by means of signs, symbols, pictograms. Into good practices dealing with deaf children, youngsters or adults belong also:

- if a hearing impaired person takes part in the mixed group, break the conversation from time to time and explain to a such person what has been said so far; in this way you free her from loneliness and isolation;

- remember that reading from your mouth is more tiring than normal listening, especially for a kid; for this reason, take breaks while talking so that a person can relax from constant concentration;

- speak calmly, not too quickly, speak accurately; sentences must be short and unambiguous, and questions should contain interrogative pronouns (who, what, when, why, where, how much, etc.);

- make sure that the conversation is accompanied by natural gestures; appropriate facial expressions and gestures make it easier to understand or guess the meaning of our speech;

- do not approach the deaf person suddenly from behind so as not to frighten him;

- do not approach too close when talking - the best distance is one meter;

- while talking, direct your face towards the deaf person so that he can read your mouth from the movement;

- participants should always be placed facing the object in question (during travelling the guide and translator are standing backwards).

For children with intellectual disabilities and some neurotic disorders intellectual disability may vary, depending on dynamics of nervous processes. Due to the many activities they perform routinely, may require assistance or a longer adjustment period in a new and unknown environment. During travelling is advised strongly to remember that some matters may be delicate. i.e.

- in catering also the menu card should be properly structured. If individual dishes are sketched or a photo is posted, the disabled consumer can easily choose the menu according to own preferences;

- an hippo therapy may be a very good form of recreation for intellectually disabled people. The use of appropriate positions and exercises during hippo therapy eliminates increased muscle tone. Contact with an animal teaches especially children sensitivity and friendship, affection and showing feelings. 
- people with intellectual disabilities are unable to receive visual experience outside the bus window. For this reason, when we want to say something about a place, we should stop. Similarly to other disabilities, the position of participants on the bus should be planned for intellectual disabilities. Additional disorders such as epilepsy, anxiety, etc. are also included.

There is important to encourage people with disabilities to carry on with their daily duties, help them focus their attention and mobilize them to act by giving very specific tasks to perform;

\section{Conclusion}

To sum up our conclusions on still evolving and so important issue there are some updated advices for parents and families with children of special needs or disabilities. The main traveling impact/issues for such families might be:

- changes in routine;

- $\quad$ tackling unexpected events;

- finding the appropriate accommodation structures;

- manage the children behavior;

- $\quad$ interacting with normal people;

- crowd;

- new noises and sights.

Planning travel in these days is an action that encompasses all the travel components and can be affected by traveling relationships. When a family plans travel should define a strategy to minimize the primary impacts/issues that can occur. To achieve a such goal, it is important to define travel in all its aspects. On this purpose, can be useful the following travel descriptors:

- trip origins;

- trip destinations;

- distance;

- travel time;

- travel duration;

- trip purpose;

- mode for trip;

- number of persons.

Lists of services that support families of children with ASD are also necessary.

Furthermore, the best practices to tackle the various issues should be identified. Best practices are also relevant to define the policies to support the traveling of families with children with ASD. The principles underlying good practice should form the conceptual basis for policies. Educational support is an important element of the model. Educational actions are needed to sustain families as well as to stimulate awareness and inclusion from "normal" people.

New technology plays a crucial role in providing information to families. Nevertheless, appropriate strategies should be identified in order to screen information available on the internet and select only reliable sources.

During a current situation of semi or full lockdowns in Poland which heavily effect tourism branch, there should be raised some governmental programs dedicated to families with disabled kids to encourage to individual tourism. Maybe there should be prepared some money transfers (ie. an alternative form of "Polish Family Support Program 500+" dedicated to families with the children with disabilities or disorders) to such families with special needs children to stabilize and save tourism in Poland too. 
The disabled people in Poland no matter of which disorder they suffer still are not respected in the context of tourist market and commercial offer. The large field of tourism might be enormous opportunity for integration and revalidation process too. Also in Poland people with disabilities or elderly have right to Accessible Tourism, which is referring to the idea of "The Philosophy of Tourism for All". This is based on the concept of Design for All. The idea behind is to design products, services and the entire environment in a way that the broadest group of users is enabled to make use of it equally (Pühretmair, 2006).

\section{References}

Analiza rozwoju turystyki społecznej w Polsce: Stan, szanse, zagrożenia (2007). Warszawa: Instytut Turystyki.

Budny, J. (2003). Projektowanie dla wszystkich. Stowarzyszenie Przyjaciót Integracja. Warszawa.

Constitution of the Republic of Poland of 2nd April. (1997). As published in Dziennik Ustaw No. 78, item 483. Retrieved from https://www.sejm.gov.pl/prawo/konst/angielski/kon1.htm

Convention on the Rights of Persons with Disabilities (CRPD). (2006). Retrieved from https://www.un.org/development/desa/disabilities/convention-on-the-rights-of-personswith-disabilities.html

Disability and Development Report Realizing the Sustainable Development Goals by, for and with persons with disabilities. (2019). Disability and Development Report Published by the United Nations. New York, New York 10017, United States of America

Grabowski, J., Milewska, M., \& Stasiak, A. (2007). Vademecum organizatora turystyki niepetnosprawnych. Łódź: Wydawnictwo WSTH.

Kaganek, K. \& Stanuch, H. (2005). Modele regresyjne uprawiania turystyki aktywnej przez osoby niepełnosprawne wzrokowo i ruchowo. Bio-Algorithms and Med.-Systems, 1, 1/2 , p. 221-226.

Kędzierska, J. (2007). Turystyka osób niewidomych i słabo widzących. In A. Borowicka, A. Borowicka, W. Heliński (Ed.), Tworzenie i dostosowywanie produktów turystycznych do potrzeb osób niepetnosprawnych (pp. 51-59). Szczecin: Wyd. Forum Turystyki Regionów.

Kobosko, K. (1999). Moje dziecko nie styszy. Materiat dla rodziców dzieci z wada stuchu. Stowarzyszenie Przyjaciół Osób Niesłyszacych i Niedosłyszacych Człowiek Człowiekowi. Warszawa.

Milewska, M. (2008). Turystyka osób niepetnosprawnych w Europie i w Polsce, in. Stasiak A. (ed.), Rola krajoznawstwa i turystyki w życiu osób niepetnosprawnych. Wydawnictwo PTTK Kraj. Warszawa.

Majewski, T. (1980). Rehabilitacja zawodowa w systemie stużby zdrowia i opieki społecznej. Warszawa: PZWL.

Pühretmair, F. (2006). People with Disabilities: Accessible Tourism. Introduction to the Special Thematic Session. In Miesenberger, K., Klaus, J., Zagler, W.L., Karshmer, A.I. (Ed.) Computers Helping People with Special Needs (pp. 295-297). Wien: Springer.

Rozporządzenie Ministra Pracy i Polityki Społecznej. (2002). In. Dz. U. Nr 17, poz. 162, z późn. zm. Retrieved from https://sip.lex.pl/orzeczenia-i-pisma-urzedowe/pisma-urzedowe/sps023-23878-11-stanowisko-mpips-w-sprawie-orzekania-o-184655049.

Rozporzadzenie Ministra Gospodarki i Pracy z dnia 19 sierpnia 2004 r. w sprawie obiektów hotelarskich i innych obiektów, w których sq świadczone usługi hotelarskie. (2004). In. 
Dz. U. z 2006 r. Nr 22, poz. 169 oraz z 2011r. Nr 259, poz. 1553. Retrieved from http://isap.sejm.gov.pl/isap.nsf/DocDetails.xsp?id=wdu20041881945.

Rozporzadzenie Ministra Infrastruktury z dnia 25 października 2002 r. w sprawie rodzajów dokumentów poświadczających uprawnienia do korzystania z ulgowych przejazdów środkami publicznego transportu zbiorowego (2002). In Dz.U. 2002 nr 179 poz. 1495. Retrieved from:

Rozporządzenie Ministra Infrastruktury z dnia 25 października 2002 r. w sprawie rodzajów dokumentów poświadczających uprawnienia do korzystania z ulgowych przejazdów środkami publicznego transportu zbiorowego. (sejm.gov.pl)

ROZPORZACDZENIE (WE) NR 1107/2006 PARLAMENTU EUROPEJSKIEGO I RADY z dnia 5 lipca 2006 r. $w$ sprawie praw osób niepetnosprawnych oraz osób o ograniczonej sprawności ruchowej podróżujących droga lotnicza. In www of the 'Urząd Lotnictwa Lądowego'. Retrieved from: ROZPORZA_DZENIE (WE) NR 1107/2006 PARLAMENTU EUROPEJSKIEGO I RADY $\mathrm{z}$ dnia 5 lipca 2006 r. $\mathrm{W}$ sprawie praw osób niepełnosprawnych oraz osób o ograniczonej sprawności ruchowej podróżujących drogą lotnicza - ULC

Skalska, T. (2004). Turystyka osób niepetnosprawnych: ograniczenia i możliwości rozwoju. Warszawa: Wyższa Szkoła Hotelarstwa, Gastronomii i Turystyki.

Sowa, J. (1999). Pedagogika specjalna w zarysie. Rzeszów: Wyd. Oświatowe FOSZE.

Strategia Rozwoju Turystyki na lata 2007-2013. (2005). Projekt Strategii Rozwoju Turystyki na lata 2007-13. Projekt rządowy. Warszawa. Retrieved from http://europedirectkatowice.pl/ed_stara_strona/dokumenty/2/strategia-rozwoju-turystyki.pdf

Suprewicz, J. (2005). Socjologia turystyki. Lublin: WSS-P w Lublinie.

Szczuciński, A. (2005). Przygotowanie psychologiczno-motoryczne i możliwości organizacyjne osób niepełnosprawnych oraz organizacji skupiających osoby o specjalnych potrzebach do udziału w ruchu turystycznym, In Międzynarodowa Konferencja Osób Niepetnosprawnych Krajoznawstwo $i$ turystyka osób niepetnosprawnych - bez granic i barrier (pp. 19-26). Warszawa: ZG PTTK.

Ustawa z dnia 20 czerwca 1997 r. Prawo o ruchu drogowym. (1997) In. Dz.U. 1997 nr 98 poz. 602. Retrieved from

http://isap.sejm.gov.pl/isap.nsf/DocDetails.xsp?id=wdu19970980602 .

Żbikowski, J. \& Soroka, A. (2011). Bariery uczestnictwa osób niepetnosprawnych w turystyce $i$ rekreacji $w$ kontekście ich sytuacji ekonomicznej. Instytut Turystyki i Rekreacji Państwowa Szkoła Wyższa im. Papieża Jana Pawła II w Białej Podlaskiej. 